\title{
TEACHERS' ATTITUDES IN APPLICATION OF TECHNOLOGY AND EFFECTIVE TEACHING PLANNING IN PRIMARY SCHOOL
}

\author{
Arjana Zhubi \\ Doctoral Student of Prishtina/Faculty of Education (Kosovo)
}

\begin{abstract}
The planning of teaching with technological tools in Kosovo schools has brought new and challenging experiences for teachers at all levels of education. The purpose of the research is to analyze the attitudes of teachers about the application of technology in effective planning of teaching and raising learning outcomes in primary school. Furthermore, the research determines the impact of age and level of teacher's education on the application of technology according to curriculum areas.

The TPACK model was used as the theoretical framework during the research, which helped us to clarify the notions: technological knowledge, pedagogical knowledge, and teaching contents in the effective planning of teaching by applying technology.

The data were collected from a questionnaire with 25 teachers in an elementary school where technology finds higher applicability in teaching. To analyze the learning outcomes during the application of technology and applicability in other subjects, the Post Hock test, and the Correlation was used to measure the relationship between the two variables, respectively the correlation between the age and the level of education of teachers.

The results of this research show that learning planning through technology affects the increase of focus and gain a higher understanding in each subject, acquiring knowledge of new concepts, raises the desire to learn independently, makes the learning process more innovative and more attractive to students.

The research recommends for the local and central level to give priority to equipping primary schools with technological tools to improve teaching by having the opportunity to plan different practices.
\end{abstract}

Keywords: Technology, teachers, lesson planning, curriculum, elementary school.

\section{Introduction}

The application of technology in teaching cannot be effective if a prior lesson plan is not prepared (Krauskopf, 2012) if the teacher's technological attitudes and knowledge are not verified (Baturay, 2017). Acknowledging this fact, during the research we will be based on the TPACK (The Technological, Pedagogical, and Content Knowledge framework) model. This model reflects the attitudes of teachers about the application of technology in the classroom (Koehler \& Mishra, 2005) and identifies three types of technology knowledge: technological knowledge, pedagogical knowledge, and knowledge of teaching content. Technological knowledge (TK), which corresponds to the attitudes of teachers regarding the application of technology, available technological resources, and the necessary skills to use them in teaching. Pedagogical knowledge (KP) refers to the way teaching and learning are developed, including the strategies, methods, and activities used by the teacher in the curricular areas and cross-curricular integration. Content knowledge (CK) refers to subject knowledge, curriculum planning, and unit development. These three interrelated areas will determine whether preparation, planning, and teaching are effectively developed using technology (Voogt, 2013), which will be used as background to understand research data.

The application of technology in teaching has been part of numerous studies around the world. Researchers investigated the effects of technology on teaching and found that in classrooms where technology is used, teaching is significantly improved compared to classrooms where teaching takes place without technology (Hixon, E., \& So, H. J., 2009; Voogt, J., \& McKenney, S., 2017). Researcher Sylvestre (2018) conducted a study with 144 teachers of 8 primary schools, where the level of technology application was very low and the teaching process resulted in poor success by students. The recommendation from this study was that the government should equip all schools with technological tools to achieve efficiency in the teaching process. The study done with these teachers was descriptive and it was concluded that the more technology is applied, the more the teaching process will develop and the learning outcomes will be significantly higher in each subject. Another study conducted in Brighton, UK, by the authors Cox and Preston (1999), examined the evidence from teachers regarding the application of technology in teaching, 
their experiences in technology, attitudes, and knowledge in the use of technological tools. The authors based on the research findings concluded that teaching takes place in attractive forms for students, traditional classrooms were transformed into digital classrooms, and that teachers were ready to start a new way of research teaching.

Recently, many researchers (Blau \& Nusan, 2014; Hermans et al., 2008; Alqurashi \& Carbonara, 2017) identified other factors that influence teachers' attitudes about the use of technology. The level of education, and the age of the teachers were particularly influential. These two aspects are closely related because without professional development the teacher will not be able to plan and organize teaching with technology, there will be no working knowledge of equipment, resources, and technological applications as supporting or integrating material in the classroom. Researchers (Alqurashi, E., Gokbel, E. N., \& Carbonara, D, 2017) explain that older teachers do not support this methodology because their level of education does not correspond to technology programs and does not even express interest in integrating technology into the classroom because of the skills, knowledge, and negative attitudes they possess (Soetan, A. K., \& Cokerb, A. D. , 2018). Being part of the training, many of them do not prefer the application of technology (Voogt, 2013). However, some older teachers put their technology skills into practice very effectively, which contradicts the ideas of many researchers that age hinders the use of technology (Sánchez-Mena et al, 2017). For this reason, the TPAC model allows to identify the specifics of teachers, their actions during the planning and use of technology in the classroom, the challenges, and the level of implementation of the technology.

Figure 1. Explanation of TPACK fields.

\begin{tabular}{|l|c|l|}
\hline \multicolumn{1}{|c|}{ Knowledge } & Abbreviations & \multicolumn{1}{c|}{ Explanation } \\
\hline Content knowledge & CK & $\begin{array}{l}\text { Knowledge of current issues of the subject being taught or should } \\
\text { be taught. Understanding the contents of curricular areas. Selects } \\
\text { relevant content for students taking into account the link between } \\
\text { subjects and curriculum areas. }\end{array}$ \\
\hline Pedagogical knowledge & PK & $\begin{array}{l}\text { Knowledge of teaching processes and methods, teaching } \\
\text { techniques and strategies. Knowledge about lesson planning. }\end{array}$ \\
\hline $\begin{array}{l}\text { Technological } \\
\text { knowledge }\end{array}$ & TK & $\begin{array}{l}\text { Knowledge of the application of technological tools/resources in } \\
\text { achieving goals. }\end{array}$ \\
\hline $\begin{array}{l}\text { Knowledge of } \\
\text { pedagogical content }\end{array}$ & PCK & $\begin{array}{l}\text { Knowledge to understand the subject matter and to find different } \\
\text { ways/methods/techniques, adaptation and integration of materials. }\end{array}$ \\
\hline $\begin{array}{l}\text { Knowledge of } \\
\text { technological content }\end{array}$ & TCK & $\begin{array}{l}\text { Knowledge to understand technology and content harmonization } \\
\text { because they can affect and limit each other. }\end{array}$ \\
\hline $\begin{array}{l}\text { Technological } \\
\text { pedagogical knowledge }\end{array}$ & TPK & $\begin{array}{l}\text { Knowledge of how to use technology in specific ways to change } \\
\text { learning and teaching. Recognition of the pedagogical benefits and } \\
\text { limitations of technologies. }\end{array}$ \\
\hline $\begin{array}{l}\text { Knowledge of } \\
\text { technological } \\
\text { pedagogical content }\end{array}$ & TPACK & $\begin{array}{l}\text { Knowledge of content integration, pedagogy, and technology. } \\
\text { Being able to learn specific content with specific techniques and } \\
\text { methods and appropriate technology. }\end{array}$ \\
\hline
\end{tabular}

\section{Research questions}

The questions that the research corresponds to are:

What are the attitudes of teachers to the application of technology in effective lesson planning? How much does technology affect students' learning outcomes, independent work and attractive learning? What are the data on the applicability of teaching technology in other subjects? What correlation exists between raising learning outcomes and making learning more attractive? What is the correlation between the age and the level of teacher's education?

\section{Method}

In this research, we used the method of quantitative research. The participants were 25 teachers of the primary school "Kelmend Rizvanolli" from Gjakova, Kosovo, working with students from grades 1-5. Sampling was intentional because this school has a personal laptop for teachers in each class.

\subsection{Instruments for data collection}

For data collection, we used the program for social sciences (SPSS). To analyze teachers' attitudes towards the application of technology in effective lesson planning we used the survey with teachers. To verify the learning outcomes during the application of technology and suitability/applicability in other subjects we used the Post Hock test and the Correlation to measure the relationship between the two variables, respectively the correlation between age and level of teacher's education. 


\section{Results}

The table below presents information on technology planning and implementation by teachers and their attitudes in implementing new technology strategies. This study reported only 1 participant (4\%) who spends more than two hours on the computer to plan any learning unit, 4 participants $(16 \%)$ stated that they spend 1 to 2 hours, while 20 participants $(80 \%)$ reported that less than 1 -hour passes on the computer planning for any subject, which means that planning with technology is organized more easily than of the traditional form. Asked about the use of technology in school, 21 participants $(88 \%)$ reported that they use it a lot, 2 reported moderately (8\%) and 1 reported using little technology in school $(4 \%)$. In the third question, 21 participants (84\%) stated that planning with technology has a very high impact and 4 participants stated slightly lower values, which means that the implementation of new strategies through technology is easier and more understandable to students.

Table 1. Teachers' attitudes towards the application of technology in effective lesson planning.

\begin{tabular}{|c|c|c|c|c|c|c|}
\hline \multirow[t]{2}{*}{$\mathrm{N}=\mathbf{2 5}$} & \multicolumn{2}{|c|}{$\begin{array}{l}\text { How much time do } \\
\text { you spend on the } \\
\text { computer planning } \\
\text { for any subject? } \\
\end{array}$} & \multicolumn{2}{|c|}{ I used technology at school: } & \multicolumn{2}{|c|}{$\begin{array}{l}\text { How much has technology } \\
\text { planning influenced the } \\
\text { implementation of new } \\
\text { strategies? }\end{array}$} \\
\hline & $\mathrm{N}$ & $\%$ & $\mathrm{~N}$ & $\%$ & $\mathrm{~N}$ & $\%$ \\
\hline Less than 1 hour & 20 & 80 & & & & \\
\hline 1 to 2 hours & 4 & 16 & & & & \\
\hline More than 2 hours & 1 & 4 & & & & \\
\hline Many & & & 21 & 88 & & \\
\hline Average & & & 2 & 8 & & \\
\hline Less & & & 1 & 4 & & \\
\hline 4 & & & & & & \\
\hline 5 & & & & & 0 & 0 \\
\hline 6 & & & & & 1 & 4 \\
\hline 7 & & & & & 1 & 4 \\
\hline 8 & & & & & 1 & 4 \\
\hline 9 & & & & & 1 & 4 \\
\hline 10 & & & & & 21 & 84 \\
\hline
\end{tabular}

This study has included 25 teachers, $12(48 \%)$ were male and $13(52 \%)$ female. In question, planning through technology affects the increase of learning outcomes in students, 23 participants (92\%) reported totally agree, $1(4 \%)$ agree and $1(4 \%)$ participant was the neutral. When they asked about a technique that influences students to learn independently and more requirements, 24 participants $(96 \%)$ stated totally agree, only 1 participant (4\%) was agreed, while no participant has been declared neutral and disagree. This situation informs us that all other schools must be supplied with technological tools.

Table 2. Technology affects the increase of learning outcomes in students, making learning attractive and independent.

\begin{tabular}{|c|c|c|c|c|c|c|}
\hline \multirow[t]{2}{*}{$\mathbf{N}=\mathbf{2 5}$} & \multicolumn{2}{|c|}{ Gender } & \multicolumn{2}{|c|}{$\begin{array}{l}\text { Planning through technology affects } \\
\text { the increase of learning outcomes in } \\
\text { students }\end{array}$} & \multicolumn{2}{|c|}{$\begin{array}{l}\text { Technology has influenced students } \\
\text { to learn independently and make } \\
\text { learning more engaging }\end{array}$} \\
\hline & $\mathrm{N}$ & $\%$ & $\mathrm{~N}$ & $\%$ & $\mathrm{~N}$ & $\%$ \\
\hline Man & 12 & 48 & & & & \\
\hline Female & 13 & 52 & & & & \\
\hline Totally agree & & & 23 & 92 & 24 & 96 \\
\hline Agree & & & 1 & 4 & 1 & 4 \\
\hline Neutral & & & 1 & 4 & & \\
\hline Disagree & & & & & & \\
\hline
\end{tabular}




\subsection{Averages}

The table below presents the data to used technology in other subjects. Participants believe that technology applied very successfully in the Natural Science subject $(M=1.36)$, English $(M=1.87)$, and Albanian language $(\mathrm{M}=1.54)$. According to the participants, the subjects in which not necessary to apply the technology were Art $(\mathrm{M}=3.52)$, Civic Education $(\mathrm{M}=3.69)$ and Physical Education $(\mathrm{M}=3.08)$.

Table 3. Average data on the applicability of teaching technology in other subjects.

\begin{tabular}{lccc}
\hline Subjects & N & M & SD \\
\hline Art & 23 & 3.52 & .98 \\
Physical education & 24 & 3.08 & .87 \\
Mathematics & 24 & 2.37 & .92 \\
Albanian language & 24 & 1.54 & .65 \\
Musical education & 25 & 2.24 & .77 \\
English language & 24 & 1.87 & .89 \\
Natural Sciences & 25 & 1.36 & .56 \\
Civic education & 23 & 3.69 & .79 \\
History & 23 & 3.00 & .90 \\
\hline
\end{tabular}

\subsection{Correlates}

The table below presents the correlation between raising learning outcomes and making learning more demanding. There is a positive signaling correlation from teacher's attitudes who express that the use of technology for new acquaintances is easier.

Also, data present that there is a positive signaling correlation between increasing success in all subjects, and the reason that teaching is made more attractive because of using the application of technology.

Table 4. Data on the correlation between raising learning outcomes and making learning more engaging.

\begin{tabular}{lcccccc}
\hline & 1 & 2 & 3 & 4 & 5 & 6 \\
\hline 1. Easier acquisition of new knowledge & - & & & & & \\
2. Interest and desire to learn more & .382 & - & & & & \\
3. Researching new information & .161 & .046 & - & & & \\
4. Increasing success in all subjects & .326 & -.035 & $.522^{* *}$ & - & & \\
5. The lesson is more appealing & .372 & .107 & .324 & $.532^{* *}$ & - & - \\
6. Expanding knowledge about the subject & $.600^{* *}$ & .371 & .023 & .220 & .241 & - \\
\hline
\end{tabular}

From the analysis of the correlation made between the age of teachers and the level of implementation of teacher education, we have confirmed that there is a low positive correlation $\mathrm{r}=.119$. This means that with the age of teachers there is a possibility that teachers will not apply technological tools. The value of the correlation makes it clear that we are moving away from the zero points or from not correlating the variables with each other. In this case, although with a weak positive correlation, the correlation between the two variables still exists in the selected sample.

\section{Conclusions and recommendations}

This study investigated the impact of technology implementation in Kosovo primary schools and the need for planning and organizing the learning process through technology. It was proved that the results of the research are in line with the international ones where technology is applied, but, equipping schools with technological tools cannot be realized due to financial means. The findings reflect that the essential attitudes of teachers towards the planning and implementation of teaching through technology are pedagogical, technological, and content knowledge, specified as the three main elements to understand the complexity of teaching with technology. Planning through technology influenced the increase of learning outcomes in students, knowledge of new concepts, deepened knowledge of the different subjects, inspired students to learn independently, and the development of more attractive learning by offering multiple selections and alternatives around the learning units. The results from the study confirmed that technology planning influenced the implementation of new strategies in the classroom by teachers as a new approach to teaching practices. Also, their age and level of education emerged as determinants in technology planning and implementation, although they had a low positive correlation. From this, it can be concluded that teachers need to start planning differently by now because technology creates and offers many opportunities 
in our schools. To push the Ministry of Education to find opportunities or donors for technological equipment in all schools in Kosovo as a permanent part of the teaching process. Education Directorates obligated to cooperate with schools to influence the creation of conditions that enable the integration of technology in all educational institutions.

\section{References}

Alqurashi, E., Gokbel, E. N., \& Carbonara, D. (2017). Teachers' knowledge in content, pedagogy and technology integration: A comparative analysis between teachers in Saudi Arabia and United States. British Journal of Educational Technology, 48(6), 1414-1426. doi:10.1111/bjet.12514

Baturay, M. H. (2017). Associations among Teachers' Attitudes towards Computer-Assisted Education and TPACK Competencies. Informatics in Education, 16(1), 1-23.

Blau, I., Peled, Y., \& Nusan, A. (2014). Technological pedagogical and content knowledge (TPACK) in one-to-one classroom: Teachers developing "Digital Wisdom". Interactive Learning Environments, 24(6), 1215-1230. doi:10.1080/10494820.2014.978792

Cox, M., Preston, C. \& Cox, K. (1999). What Factors Support or Prevent Teachers from Using ICT in their Classrooms? Paper presented at the British Educational Research Association Annual Conference. University of Sussex, Brighton.

Hermans, R., Tondeur, J., Van Braak, J., \& Valcke, M. (2008). The impact of primary school teachers' educational beliefs on the classroom use of computers. Computers \& Education, 51(4), 1499-1509. doi:10.1016/j.compedu.2008.02.001

Hixon, E., \& So, H. J. (2009). Technology's role in field experiences for preservice teacher training. Educational Technology \& Society, 12(4), 294-304. Retrieved from learntechlib.org/p/74980/

Koehler \& Mishra. (2005). What happens when teachers design educational technology? The development of technological pedagogical content knowledge. Journal of Educational Computing Research, 32(2), 131-152. doi:10.2190/0EW7-01WB-BKHL-QDYV

Krauskopf, K. Z. (2012). Leveraging the affordances of Youtube: The role of pedagogical knowledge and mental models of technology functions for lesson planning with technology. Computers \& Education, 50(4), 1194-1206. doi:10.1016/j.compedu.2011.12.010

Sánchez-Mena, A., Martí-Parreño, J., \& Aldás-Manzano, J. (2017). The Effect of Age on Teachers' Intention to Use Educational Video Games: A TAM Approach. Electronic Journal of e-Learning, 15(4), 355-366.

Soetan, A. K., \& Cokerb, A. D. . (2018). University lecturers' readiness and motivation in utilizing online technologies for instructional delivery in Kwara state, Nigeria. World Journal on Educational Technology, 10(4), 165-181. doi:10.18844/wjet.v10i4.408

Sylvestre, M. H. (2018). Information communication technology policy and public primary schools` efficiency in Rwanda. South African Journal of Education, 38(1). doi:10.15700/saje.v38n1a1445

Voogt, J. F. (2013). Technological pedagogical content knowledge-a review of the literature. Journal of Computer Assisted Learning, 29(2), 109-121. doi:10.1111/j.1365-2729.2012.00487

Voogt, J., \& McKenney, S. (2017). TPACK in teacher education: Are we preparing teachers to use technology for early literacy. Technology, pedagogy and education, 26(1), 69-83. doi:10.1080/1475939X.2016.1174730 